\title{
Influence of organic and inorganic fertilizers on productivity and storage ability of sweet pepper
}

\author{
Said A. Shehata ${ }^{1}$, Mohamed M. El-Mogy ${ }^{1}$, Ahmed A. Gharib ${ }^{1}$, Mohamed A. Rahgh ${ }^{2}$. \\ ${ }^{1}$ Cairo University, Faculty of Agriculture, Vegetable Crops Department, Giza, Egypt. \\ ${ }^{2}$ Agriculture Research Center, Postharvest Department, Giza, Egypt.
}

\begin{abstract}
Two field experiments were conducted during the two successive winter seasons of 2010/2011 and 2011/2012 under green house conditions in a private farm at Fayed district, Ismailia Governorate to investigate the response of sweet pepper plants, Monist F1 hybrid, to the organic fertilizers (compost, rock phosphate with different rates of rock potassium $\left(1.78,2.34\right.$ and $\left.3.00 \mathrm{~kg} / 30 \mathrm{~m}^{2}\right)$ and inorganic fertilizer (100 kg ammonium nitrate +70 litre phosphoric acid $\left(85 \% \mathrm{P}_{2} \mathrm{O}_{5}\right)+200 \mathrm{~kg}$ potassium sulphat $\left.\left(48 \% \mathrm{~K}_{2} \mathrm{O}\right) / 540 \mathrm{~m}^{2}\right)$. The highest potassium rates (2.34 and $3.00 \mathrm{~kg} / 30 \mathrm{~m}^{2}$ plus compost and rock phosphate) and mineral fertilizers treatment (control) enhanced vegetative growth characteristics, early yield, total yield, physical and chemical properties of sweet pepper fruits. There was no difference between control (mineral fertilizer) and the highest potassium rates (2.34 and $3.00 \mathrm{~kg} / 30 \mathrm{~m}^{2}$ ). Weight loss and decay scores were decreased by using of the high rates of potassium fertilizers while, the general appearance and firmness of fruits were increased. Mineral fertilizer (control) showed the lowest quality parameters. The highest TSS, ascorbic acids and carotenoid contents were resulted from the two highest rates of rock potassium fertilizers. Thus organic fertilizers of sweet pepper plants could be an alternative to conventional fertilizer.
\end{abstract}

Key words: rock potassium, capsicum annuum, yield, storage ability

\section{Introduction}

Sweet pepper is one of the Solanaceae family members which grown intensively in Egypt. It has a high $\mathrm{K}$ demand and the harvested fruit removes a large amount of $\mathrm{K}$ from the soil. Pepper plant requires higher amounts of $\mathrm{K}$ and more responsive to proper amount of $\mathrm{K}$ (El-bassiony et al., 2010).Organic fertilizers such as compost, rock phosphate and rock potassium are good sources for macro and microelements that essential for plant growth, it is also enhance soil fertility for both sandy and clay soils (Badr, 2006).

Potassium (K) is an essential plant mineral element (nutrient) having a significant influence on increasing many human-health related quality compounds in fruits and vegetables (Usherwood, 1985). Potassium is one of sixteen essential nutrients required for plant growth and reproduction. It is classified as a macronutrient. While potassium is not a constituent of any plant structures or compounds, it plays a part in many important regulatory roles in the plant.

Application of natural fertilizer such as rock phosphate and feldspar caused the release of macro elements and converted those to soluble form of $\mathrm{P}$, $\mathrm{K}$, $\mathrm{Ca}$ and $\mathrm{Mg}$ in comparison with the compost without natural rocks (El-Naggar et al., 2004).

Various sweet pepper fertilizer treatments that increased vegetative growth, yield and fruit quality have been investigated (El- Masry, 2000; Nassar et al., 2001; Fawzy et al., 2005) on sweet pepper. Plants receiving higher $\mathrm{K}$ applications matured earlier and had significantly higher total soluble solids concentration and less post harvest physiological weight loss, therefore retain texture and structure of fruits (Lester et al., 2006). There are limited previous reports on the effect of potassium fertilizer on sweet pepper fruit quality and storage ability. Thus, the present study was carried out to determine the effect of organic and inorganic fertilizers on growth, productivity, fruit quality and storage ability of sweet pepper.

\section{Materials and Methods}

This experiment was carried out under plastic house conditions during the winter seasons of 2010 /2011 and 2011/2012 in a private farm at Fayed district, Ismailia Governorate. The experimental soil was sandy loam. Seeds of sweet pepper (Capsicum annuum, L.) Monist F1 hybrid were sown in the nursery on $11^{\text {th }}$ and $13^{\text {th }}$ of September in 2010 and 2011, respectively, and the seedling were transplanted on 25th of October in both seasons. The plastic house was $60 \mathrm{~m}$ long and $9 \mathrm{~m}$ wide $\left(540 \mathrm{~m}^{2}\right)$ was divided into five ridges $(1 \mathrm{~m}$ wide and $60 \mathrm{~m}$ long) with two rows on each ridge and $50 \mathrm{~cm}$ between rows. The experiment occupied three ridges. Seedlings were planted on the two rows of each ridge $50 \mathrm{~cm}$ apart.

\section{The treatments were as follows}

1- $75 \mathrm{~kg}$ Compost $+1.53 \mathrm{~kg}$ Rock Phosphate + $1.78 \mathrm{~kg}$ Rock Potassium / $30 \mathrm{~m}^{2}$ (T1). 
2- 75 kg Compost +1.53 kg Rock Phosphate + $2.34 \mathrm{~kg}$ Rock Potassium / $30 \mathrm{~m}^{2}$ (T2).

3- $75 \mathrm{~kg}$ Compost $+1.53 \mathrm{~kg}$ Rock Phosphate + 3.00 kg Rock Potassium / 30 m² (T3).

4- Mineral fertilization (NPK), Control (T4).

The compost at $75 \mathrm{~kg} / 30 \mathrm{~m}^{2}$ and rock phosphate at $1.53 \mathrm{~kg} / 30 \mathrm{~m}^{2}$ were added for all treatments during soil preparation. However, rock potassium was conducted two times by solving the amount of rock potassium in 30 liter of water. Half of the solution was applied to each plant ( $1 / 2$ litre/plant). The chemical fertilizers were added during soil preparation as follows: $50 \mathrm{~kg}$ calcium super phosphate $\left(15.5 \% \mathrm{P}_{2} \mathrm{O}_{5}\right), 25 \mathrm{~kg}$ potassium sulphate $\left(48 \% \mathrm{~K}_{2} \mathrm{O}\right), 25 \mathrm{~kg}$ ammonium sulphate $(20.5 \% \mathrm{~N})$ and $15 \mathrm{~kg}$ sulphur.

The chemical fertilization was followed during the growing season according the recommendation of Ministry of Agricultural at $100 \mathrm{~kg}$ ammonium nitrate $(33 \% \mathrm{~N})+70$ litre phosphoric acid $\left(85 \% \mathrm{P}_{2} \mathrm{O}_{5}\right)+$ $200 \mathrm{~kg}$ potassium sulphat $\left(48 \% \mathrm{~K}_{2} \mathrm{O}\right) / 540 \mathrm{~m}^{2}$. The amounts of fertilizers were divided and added manual and separately for each plant two time from the begin of fertilization (30 days from transplanting) till the beginning of flowering and then three times weekly till the end of harvest.

The previous treatments were arranged in three replicates using complete randomized block design. The area of each plot was $10 \mathrm{~m}^{2}$ with 20 plants. Each plot contained one replicate. Drip irrigation system and agricultural practices were followed as recommended. Physical and chemical analysis of soil before planting (Table 1) and Compost (Table 2) were determined at the Soil and Water Research Institute ARC.

Table 1. Physical and chemical characteristic of experimental soil.

\begin{tabular}{ll}
\hline Soil characteristic & $\begin{array}{l}\text { Average } \\
\mathbf{2 0 1 0} \text { - 2011 }\end{array}$ \\
\hline Particle size distribution (\%) & \\
Coarse sand & 8.6 \\
Fine sand & 64.4 \\
Silt & 16.3 \\
Clay & 10.7 \\
Texture & Sandy loam \\
EC ds/m & 3.96 \\
${ }_{\mathrm{p}} \mathrm{H}$ & 7.9 \\
$\mathrm{HCO}$ (meq/l) & 1.65 \\
$\mathrm{CO} 3(\mathrm{meq} / \mathrm{l})$ & 0 \\
$\mathrm{SO} 4(\mathrm{meq} / \mathrm{l})$ & 18.29 \\
$\mathrm{Ca}(\mathrm{meq} / \mathrm{l})$ & 12.12 \\
$\mathrm{Mg}(\mathrm{meq} / \mathrm{l})$ & 4.84 \\
$\mathrm{Cl}(\mathrm{meq} / \mathrm{l})$ & 20.02 \\
$\mathrm{Na}(\mathrm{meq} / \mathrm{l})$ & 22 \\
$\mathrm{~N}(\mathrm{mg} / \mathrm{kg})$ & 98 \\
$\mathrm{P}(\mathrm{mg} / \mathrm{kg})$ & 61.48 \\
$\mathrm{~K}(\mathrm{mg} / \mathrm{kg})$ & 590 \\
\hline
\end{tabular}

Table 2. Chemical analysis of compost.

\begin{tabular}{ll}
\hline Properties & Compost \\
\hline $\mathrm{N}(\%)$ & 1.19 \\
$\mathrm{P}(\%)$ & 0.26 \\
$\mathrm{~K}(\%)$ & 0.85 \\
$\mathrm{PH}$ & 6.69 \\
$\mathrm{EC}(\mathrm{ds} / \mathrm{m})$ & 2.09 \\
$\mathrm{C} / \mathrm{N}$ ratio & $23.73: 1$ \\
Organic matter $(\%)$ & 48.71 \\
\hline
\end{tabular}

The following data were recorded:

Vegetative growth: A random samples of 5 plants from each replicate was taken after 45 days from transplanting and the following data were recorded: Plant height $(\mathrm{cm})$, number of leaves per plant and number of stems per plant.

Yield and its components: Total number of fruits / plant, early yield (determined for the three first pickings and calculated as average fresh weight of fruits $\mathrm{kg}$ /plot and average number of fruits No/plot) and total yield (determined and calculated as total fresh weight of fruits $\mathrm{kg} / \mathrm{plot}$ and total number of fruits No/plot, that were harvested from first week January to last week June throughout the whole season).

Fruit characteristics: A random sample of 10 fruits from each replicate was taken at harvest and examined for the following characters: Physical properties (Fruit length and diameter $(\mathrm{cm})$, flesh thickness (mm), average fruit weight (g) and firmness $\left(\mathrm{kg} / \mathrm{cm}^{2}\right)$ and Chemical properties (fruit dry matter (\%), total soluble solids (T.S.S) percentages (determined by using referactometer) and Ascorbic acid (mg / 100g fruit fresh weight).

\section{Storage experiment}

Sweet pepper fruits which obtained from the previous experiments were harvested at 3/4 yellow color stage on January 15th and 17th in the first and second season, respectively, then transported to the laboratory of Handling of Vegetable Crops Department, Giza Governorate, where sound and healthy fruits were chosen and free from each blemishes were selected to storage experiment.

Twelve replicates were prepared for each treatment. Each replicate consisted of 3 fruits and placed in carton box $(20 \times 15 \times 10 \mathrm{~cm})$. All treatments were stored at $10^{\circ} \mathrm{C}$ and $90-95 \%$ relative humidity. Complete randomized design was adopted. Three replicates from each treatment were taken at random and examined every seven days intervals for the postharvest properties. The following properties were examined:

Physical properties: Weight loss (\%). (Calculated from the difference between initial and final weight and expressed as percentage of the initial fresh weight), general appearance was 
measured on scale of $(9=$ excellent, $7=$ good, $5=$ fair, 3 = poor, 1 = un salable and fruits ratting (5) or below were considered un marketable), decay was measured on scale of $1=$ non, $2=$ slight, $3=$ moderate, 4=sever, 5=extreme and fruits ratting (3) or below were considered un marketable, firmness $\left(\mathrm{kg} / \mathrm{cm}^{2}\right)$.

Chemical properties: Total soluble solids percentages (T.S.S) determined by using referactometer as described according to AOAC (1980), ascorbic acid content ( $\mathrm{mg} / \mathrm{100g}$ fruit fresh weight) determined by titration method using 2.6 dichloro-phenole-end-phenole as described in AOAC (1980) and total carotenoids content (mg/kg fresh weight).

\section{Statistical analyses}

All data were subjected to the statistical analysis according to the method described by Snedechor and Cochran 1980.
Results

Vegetative growth: The effect of organic and mineral fertilizers on plant height, number of leaves and number of stems per plant is presented in Table 3. In both seasons, plant height, number of leaves and number of stems per plant were greater in plots that received mineral fertilizer (control) than in those that received all other fertilizer treatments. However, there was no significant difference among control treatment and T2 \&T3 for plant height and number of stems per plant in both seasons.

Yield: As shown in Table 4, number of fruits per plant, weight of fruits per plant, early yield and total yield were significantly higher in plots that received higher amounts of rock potassium (T2 and T3) than those plots that received the fewer rates (T1). In addition, no statistically different was found between the control treatment and T2 and T3 treatments in both seasons.

Table 3. Effect of rock potassium fertilization on the vegetative growth of sweet pepper plant in 2010 - 2011 and 2011 - 2012 seasons.

\begin{tabular}{lccc|ccc}
\hline \multirow{2}{*}{ Treatments } & \multicolumn{3}{c}{ 2010/2011 seasons } & \multicolumn{3}{c}{ 2011/2012 seasons } \\
\cline { 2 - 7 } & $\begin{array}{c}\text { Plant height } \\
(\mathrm{cm})\end{array}$ & $\begin{array}{c}\text { No. of leaves } \\
\text { / plant }\end{array}$ & $\begin{array}{c}\text { No. of stems } \\
\text { / plant }\end{array}$ & $\begin{array}{c}\text { Plant height } \\
\text { (cm) }\end{array}$ & $\begin{array}{c}\text { No. of leaves } \\
\text { / plant }\end{array}$ & $\begin{array}{c}\text { No. of stems } \\
\text { / plant }\end{array}$ \\
\hline T1 & 46.54 & 177.33 & 16.33 & 49.54 & 175.67 & 15.83 \\
T2 & 49.57 & 188.67 & 18.00 & 51.54 & 189.83 & 18.17 \\
T3 & 50.11 & 186.33 & 18.10 & 51.42 & 185.00 & 18.00 \\
T4 & 50.86 & 193.67 & 18.40 & 52.12 & 193.00 & 18.33 \\
\hline LSD at 5\% & 2.35 & 3.54 & 1.22 & 1.57 & 3.18 & 1.80 \\
\hline
\end{tabular}

$\mathrm{T} 1=75 \mathrm{~kg}$ Compost $+1.53 \mathrm{~kg}$ Rock Phosphate $+1.78 \mathrm{~kg}$ Rock Potassium.

$\mathrm{T} 2=75 \mathrm{~kg}$ Compost $+1.53 \mathrm{~kg}$ Rock Phosphate +2.34 kg Rock Potassium.

$\mathrm{T} 3=75 \mathrm{~kg}$ Compost $+1.53 \mathrm{~kg}$ Rock Phosphate $+3.00 \mathrm{~kg}$ Rock Potassium

T4 = Mineral fertilization (NPK), Control.

Table 4. Effect of rock potassium fertilization on early and total yield of sweet pepper plant in 2010 - 2011 and 2011 - 2012 seasons.

\begin{tabular}{lcccc|cccc}
\hline & \multicolumn{3}{c}{ 2010 - 2011 Seasons } & \multicolumn{3}{c}{ 2011 - 2012 Seasons } \\
\cline { 2 - 9 } Treatments & $\begin{array}{c}\text { No. of } \\
\text { fruit / } \\
\text { plant }\end{array}$ & $\begin{array}{c}\text { Weight of } \\
\text { fruits/plant } \\
(\mathrm{kg})\end{array}$ & $\begin{array}{c}\text { Early } \\
\text { yield } \\
(\mathrm{kg}) / \mathrm{plot}\end{array}$ & $\begin{array}{c}\text { Total } \\
\text { yield } \\
(\mathrm{kg}) / \mathrm{plot}\end{array}$ & $\begin{array}{c}\text { No. of } \\
\text { fruit / } \\
\text { plant }\end{array}$ & $\begin{array}{c}\text { Weight of } \\
\text { fruits/plant } \\
(\mathrm{kg})\end{array}$ & $\begin{array}{c}\text { Early } \\
\text { yield } \\
(\mathrm{kg}) / \mathrm{plot}\end{array}$ & $\begin{array}{c}\text { Total } \\
\text { yield } \\
(\mathrm{kg}) / \mathrm{plot}\end{array}$ \\
\hline T1 & 14.67 & 3.66 & 37.38 & 85.77 & 14.00 & 3.47 & 37.00 & 84.87 \\
T2 & 16.10 & 4.38 & 41.83 & 92.15 & 15.43 & 4.16 & 41.40 & 90.43 \\
T3 & 16.23 & 4.40 & 42.03 & 92.18 & 15.67 & 4.18 & 41.65 & 90.47 \\
T4 & 16.43 & 4.43 & 42.33 & 92.20 & 15.83 & 4.20 & 41.97 & 90.51 \\
\hline LSD at 5\% & 1.48 & 0.68 & 3.69 & 2.77 & NS & 0.31 & 3.25 & 3.47 \\
\hline T1 = 75 kg Compost + 1.53 kg Rock Phosphate + 1.78 kg Rock Potassium. & & & & \\
T2 = 75 kg Compost + 1.53 kg Rock Phosphate + 2.34 kg Rock Potassium. & & & & & \\
T3 = 75 kg Compost + 1.53 kg Rock Phosphate + 3.00 kg Rock Potassium. & & & & & & \\
T4 = Mineral fertilization (NPK), Control. &
\end{tabular}

Sweet pepper fruits characteristics: The effect of organic and mineral fertilizers on average weight, length, diameter and flesh thickness of fruits in 2010 and 2011 is presented in Table 5. No significant differences were observed between the control treatments and the rock potassium treatments from $\mathrm{T} 2$ and T3 treatments in average fruit weight, length, diameter and flesh thickness of fruits. The lowest value of all fruit characteristics was recorded in case of plants that received lowest rate of potassium fertilizer (T1).

Sweet pepper fruits chemical compositions: Dry matter percentage was significantly lower in T1 and control (T4) than T2 and T3 in both seasons (Table $6)$. The same trends were recorded for firmness, TSS and ascorbic acid content of sweet pepper fruits. 
Table 5. Effect of rock potassium fertilization on physical properties of sweet pepper fruit in 2010 - 2011 and 2011 - 2012 seasons.

\begin{tabular}{lcccc|cccc}
\hline & \multicolumn{3}{c}{$2010-2011$ Seasons } \\
\cline { 2 - 10 } Treatments & $\begin{array}{c}\text { Average } \\
\text { weight of } \\
\text { fruits }(\mathrm{g})\end{array}$ & $\begin{array}{c}\text { Length of } \\
\text { fruits } \\
(\mathrm{cm})\end{array}$ & $\begin{array}{c}\text { Diameter } \\
\text { of fruits } \\
(\mathrm{cm})\end{array}$ & $\begin{array}{c}\text { Flesh } \\
\text { thickness } \\
\text { of fruits } \\
(\mathrm{mm})\end{array}$ & $\begin{array}{c}\text { Average } \\
\text { weight of } \\
\text { fruits } \\
(\mathrm{gm})\end{array}$ & $\begin{array}{c}\text { Length of } \\
\text { fruits } \\
(\mathrm{cm})\end{array}$ & $\begin{array}{c}\text { Diameter } \\
\text { of fruits } \\
(\mathrm{cm})\end{array}$ & $\begin{array}{c}\text { Flesh } \\
\text { thickness } \\
\text { of fruits } \\
(\mathrm{mm})\end{array}$ \\
\hline T1 & 248.88 & 7.12 & 7.04 & 7.08 & 247.98 & 7.80 & 8.03 & 7.00 \\
T2 & 271.61 & 8.00 & 7.82 & 7.35 & 265.93 & 9.00 & 8.79 & 7.23 \\
T3 & 271.93 & 8.02 & 7.88 & 7.40 & 266.18 & 9.07 & 8.80 & 7.30 \\
T4 & 270.42 & 8.08 & 7.94 & 7.12 & 264.25 & 9.12 & 8.92 & 7.10 \\
\hline LSD at 5\% & 20.64 & 0.73 & 0.78 & 0.15 & 11.26 & 0.55 & 0.33 & 0.15 \\
\hline
\end{tabular}

T1 $=75 \mathrm{~kg}$ Compost $+1.53 \mathrm{~kg}$ Rock Phosphate $+1.78 \mathrm{~kg}$ Rock Potassium.

$\mathrm{T} 2=75 \mathrm{~kg}$ Compost $+1.53 \mathrm{~kg}$ Rock Phosphate $+2.34 \mathrm{~kg}$ Rock Potassium.

T3 $=75$ kg Compost +1.53 kg Rock Phosphate +3.00 kg Rock Potassium.

T4 = Mineral fertilization (NPK), Control.

Table 6. Effect of rock potassium fertilization on chemical properties of sweet pepper fruit in 2010 - 2011 and 2011 - 2012 seasons.

\begin{tabular}{|c|c|c|c|c|c|c|c|c|}
\hline \multirow[b]{2}{*}{ Treatments } & \multicolumn{4}{|c|}{2011 - 2010Seasons } & \multicolumn{4}{|c|}{2012 - 2011Seasons } \\
\hline & $\begin{array}{c}\text { Dry } \\
\text { matter } \\
(\%)\end{array}$ & $\begin{array}{l}\text { Firmness } \\
\left(\mathrm{kg} / \mathrm{cm}^{2}\right)\end{array}$ & $\begin{array}{r}\text { T.S.S } \\
(\%)\end{array}$ & $\begin{array}{c}\text { Ascorbic } \\
\text { acid } \\
\text { (mg/100 g } \\
\text { F.w) }\end{array}$ & $\begin{array}{c}\text { Dry } \\
\text { matter } \\
(\%)\end{array}$ & $\begin{array}{l}\text { Firmness } \\
\left(\mathrm{kg} / \mathrm{cm}^{2}\right)\end{array}$ & $\begin{array}{r}\text { T.S.S } \\
(\%)\end{array}$ & $\begin{array}{c}\text { Ascorbic } \\
\text { acid } \\
\text { (mg/100 g } \\
\text { F.w) }\end{array}$ \\
\hline $\mathrm{T} 1$ & 8.73 & 220.17 & 7.90 & 121.17 & 8.58 & 213.70 & 7.79 & 121.65 \\
\hline $\mathrm{T} 2$ & 9.15 & 224.30 & 8.02 & 124.19 & 9.00 & 220.10 & 7.98 & 124.26 \\
\hline Т3 & 9.17 & 224.20 & 7.97 & 123.80 & 9.10 & 220.00 & 7.93 & 123.86 \\
\hline $\mathrm{T} 4$ & 8.92 & 220.62 & 7.80 & 120.67 & 8.61 & 210.33 & 7.70 & 121.11 \\
\hline LSD at $5 \%$ & 0.20 & 3.54 & 0.12 & 1.70 & 0.37 & 6.36 & 0.14 & 2.37 \\
\hline
\end{tabular}

T1 = 75 kg Compost + 1.53 kg Rock Phosphate + 1.78 kg Rock Potassium.

$\mathrm{T} 2=75 \mathrm{~kg}$ Compost $+1.53 \mathrm{~kg}$ Rock Phosphate $+2.34 \mathrm{~kg}$ Rock Potassium.

$\mathrm{T} 3=75 \mathrm{~kg}$ Compost $+1.53 \mathrm{~kg}$ Rock Phosphate $+3.00 \mathrm{~kg}$ Rock Potassium.

T4 = Mineral fertilization (NPK), Control.

Weight loss of pepper fruits: The effect of organic and mineral fertilizers on weight loss percentage of sweet pepper fruits during storage at $10^{\circ} \mathrm{C}$ in 2010 and 2011 is presented in Table 7. Weight loss was increased with the increasing of storage period. During all storage periods, the lowest weigh loss value was observed in T2 followed by T3, T1. The highest weight loss ratio was recorded for mineral fertilizer treatment (control).

Table 7. Effect of rock potassium fertilization on weight loss (\%) of sweet pepper fruit during storage at $10^{\circ} \mathrm{C}$ in 2010 - 2011 and 2011 - 2012 seasons.

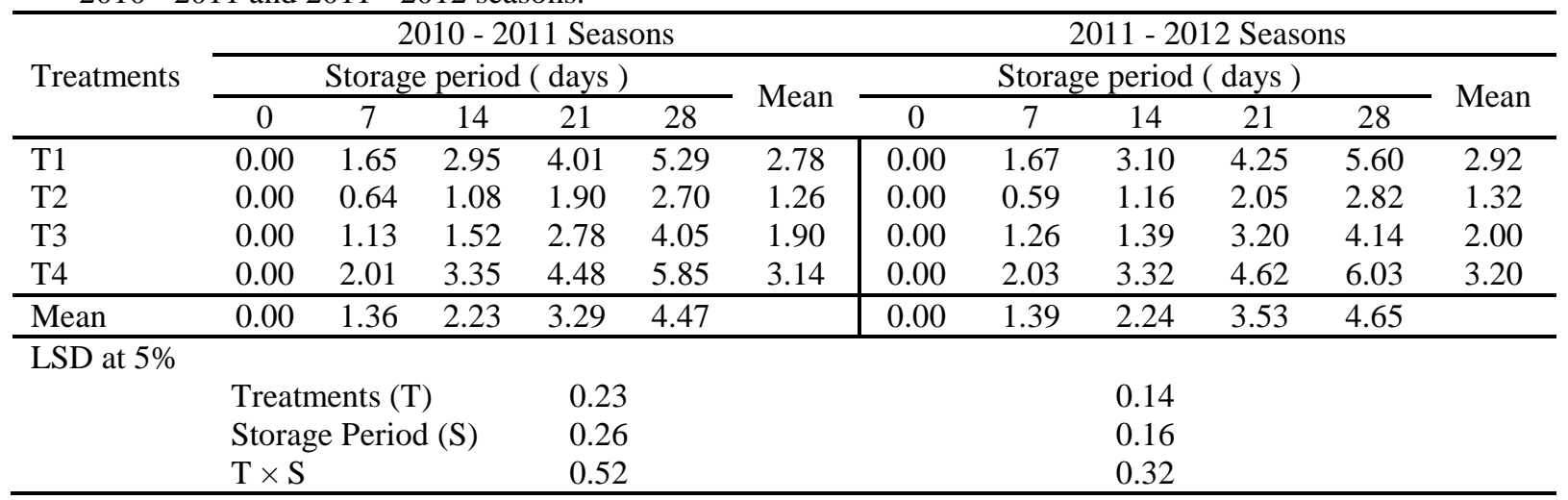

T1 $=75$ kg Compost +1.53 kg Rock Phosphate +1.78 kg Rock Potassium.

$\mathrm{T} 2=75 \mathrm{~kg}$ Compost $+1.53 \mathrm{~kg}$ Rock Phosphate $+2.34 \mathrm{~kg}$ Rock Potassium.

$\mathrm{T} 3=75 \mathrm{~kg}$ Compost $+1.53 \mathrm{~kg}$ Rock Phosphate $+3.00 \mathrm{~kg}$ Rock Potassium.

T4 = Mineral fertilization (NPK), Control. 
General appearance of pepper fruits: In 2010 and 2011, after 14 days of storage, no decrease of appearance was observed in T2 and T3 while, less reduction of appearance was recorded for $\mathrm{T} 1$ and the control (Table 8). At the end of storage period (28 d), the best general appearance was recorded for T2 and $\mathrm{T} 3$ in both seasons. The worst general appearance was recorded for mineral fertilizer treatment.

Decay score of pepper fruits: The effect of organic and mineral fertilizers on decay score of pepper fruits in 2010 and 2011 is presented in Table 9. No decay symptoms of storage period, the highest decay score was recorded for mineral fertilizer treatment while, the lowest values were recorded for T2 and T3.

Firmness of pepper fruits: The effect of organic and mineral fertilizers on firmness of sweet pepper fruits in 2010 and 2011 is presented in Table 10. Firmness of sweet peeper fruits was decreased with the increasing of storage periods. The highest firm fruits were obtained from plants which treated by high rock potassium level T2 and T3). The control treatment and $\mathrm{T} 1$ showed the lowest firmness of sweet pepper fruits.

Chemical composition of sweet pepper fruits during storage: The effect of organic and mineral fertilizers potassium on TSS, ascorbic acids and carotenoids of sweet pepper fruits is presented in Tables 11, 12 and 13. In 2010 and 2011, total soluble solids, ascorbic acids and carotenoids percentage were significantly increased until 14 days of storage, and then decreased until the end of storage period (Tables 11, 12 and 13). During storage periods, the highest TSS ascorbic acids and carotenoids values were obtained from T2 and T3 treatments.

Table 8. Effect of some pre harvest treatments on general appearance (score) of sweet pepper fruit during storage at $10^{\circ} \mathrm{C}$ in $2010-2011$ and $2011-2012$ seasons

\begin{tabular}{|c|c|c|c|c|c|c|c|c|c|c|c|c|}
\hline \multirow{3}{*}{ Treatments } & \multicolumn{6}{|c|}{2010 - 2011 Seasons } & \multicolumn{6}{|c|}{2011 - 2012 Seasons } \\
\hline & \multicolumn{5}{|c|}{ Storage period ( days ) } & \multirow{2}{*}{ Mean } & \multicolumn{5}{|c|}{ Storage period ( days ) } & \multirow{2}{*}{ Mean } \\
\hline & 0 & 7 & 14 & 21 & 28 & & 0 & 7 & 14 & 21 & 28 & \\
\hline $\mathrm{T} 1$ & 9.00 & 9.00 & 7.67 & 7.00 & 5.00 & 7.53 & 9.00 & 9.00 & 7.67 & 6.33 & 4.33 & 7.27 \\
\hline $\mathrm{T} 2$ & 9.00 & 9.00 & 9.00 & 8.33 & 7.00 & 8.47 & 9.00 & 9.00 & 9.00 & 7.67 & 7.00 & 8.33 \\
\hline T3 & 9.00 & 9.00 & 9.00 & 7.67 & 7.00 & 8.33 & 9.00 & 9.00 & 9.00 & 8.33 & 6.33 & 8.33 \\
\hline $\mathrm{T} 4$ & 9.00 & 7.67 & 6.33 & 3.00 & 1.00 & 5.40 & 9.00 & 8.33 & 5.67 & 3.67 & 1.00 & 5.53 \\
\hline Mean & 9.00 & 8.67 & 8.00 & 6.50 & 5.00 & & 9.00 & 8.83 & 7.83 & 6.50 & 4.67 & \\
\hline \multicolumn{13}{|l|}{ LSD at $5 \%$} \\
\hline & \multicolumn{3}{|c|}{ Treatments (T) } & \multicolumn{2}{|c|}{0.43} & \multicolumn{7}{|c|}{0.57} \\
\hline & \multicolumn{3}{|c|}{ Storage Period (S) } & \multicolumn{2}{|c|}{0.48} & \multicolumn{7}{|c|}{0.64} \\
\hline & \multicolumn{3}{|c|}{$\mathrm{T} \times \mathrm{S}$} & \multicolumn{2}{|c|}{0.95} & \multicolumn{7}{|c|}{1.28} \\
\hline
\end{tabular}

T1 $=75$ kg Compost +1.53 kg Rock Phosphate +1.78 kg Rock Potassium.

$\mathrm{T} 2=75 \mathrm{~kg}$ Compost $+1.53 \mathrm{~kg}$ Rock Phosphate $+2.34 \mathrm{~kg}$ Rock Potassium.

$\mathrm{T} 3=75 \mathrm{~kg}$ Compost $+1.53 \mathrm{~kg}$ Rock Phosphate $+3.00 \mathrm{~kg}$ Rock Potassium .

T4 = Mineral fertilization (NPK), Control.

Table 9. Effect of rock potassium fertilization on decay (score) of sweet pepper fruit during storage at $10^{\circ} \mathrm{C}$ in $2010-2011$ and $2011-2012$ seasons.

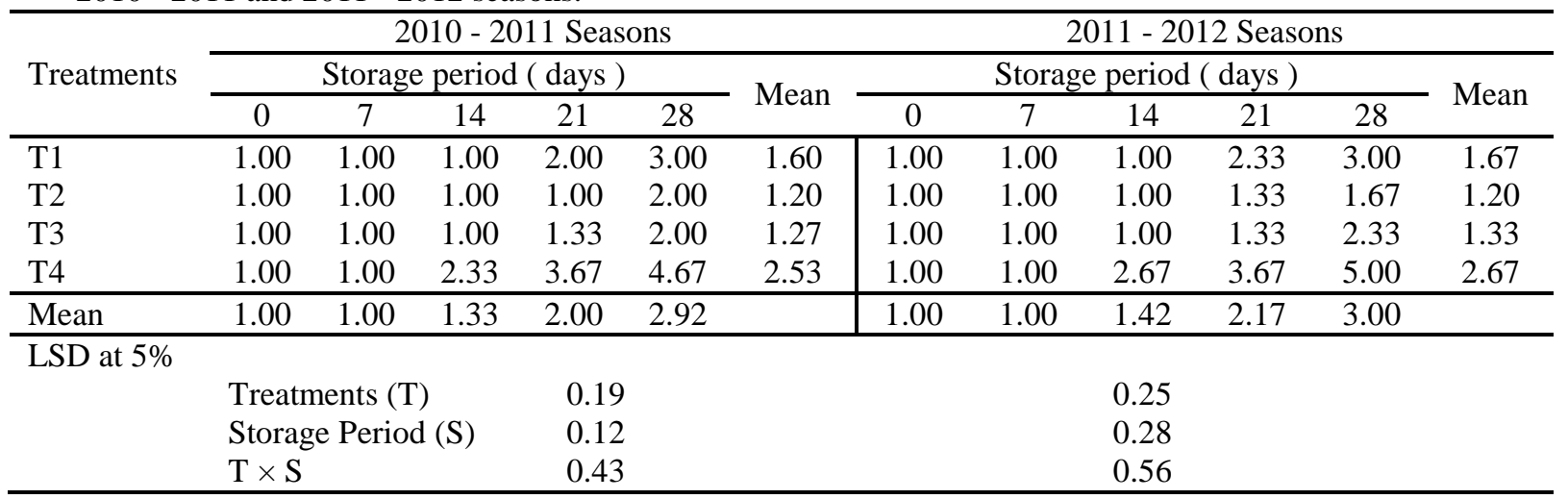

$\mathrm{T} 1=75 \mathrm{~kg}$ Compost $+1.53 \mathrm{~kg}$ Rock Phosphate $+1.78 \mathrm{~kg}$ Rock Potassium.

$\mathrm{T} 2=75 \mathrm{~kg}$ Compost $+1.53 \mathrm{~kg}$ Rock Phosphate $+2.34 \mathrm{~kg}$ Rock Potassium .

T3 $=75 \mathrm{~kg}$ Compost $+1.53 \mathrm{~kg}$ Rock Phosphate $+3.00 \mathrm{~kg}$ Rock Potassium.

T4 = Mineral fertilization (NPK), Control. 
Table 10. Effect of rock potassium fertilization on firmness $\left(\mathrm{kg} / \mathrm{cm}^{2}\right)$ of sweet pepper fruit during storage at $10^{\circ}$ C in 2010 - 2011 and 2011 - 2012 seasons.

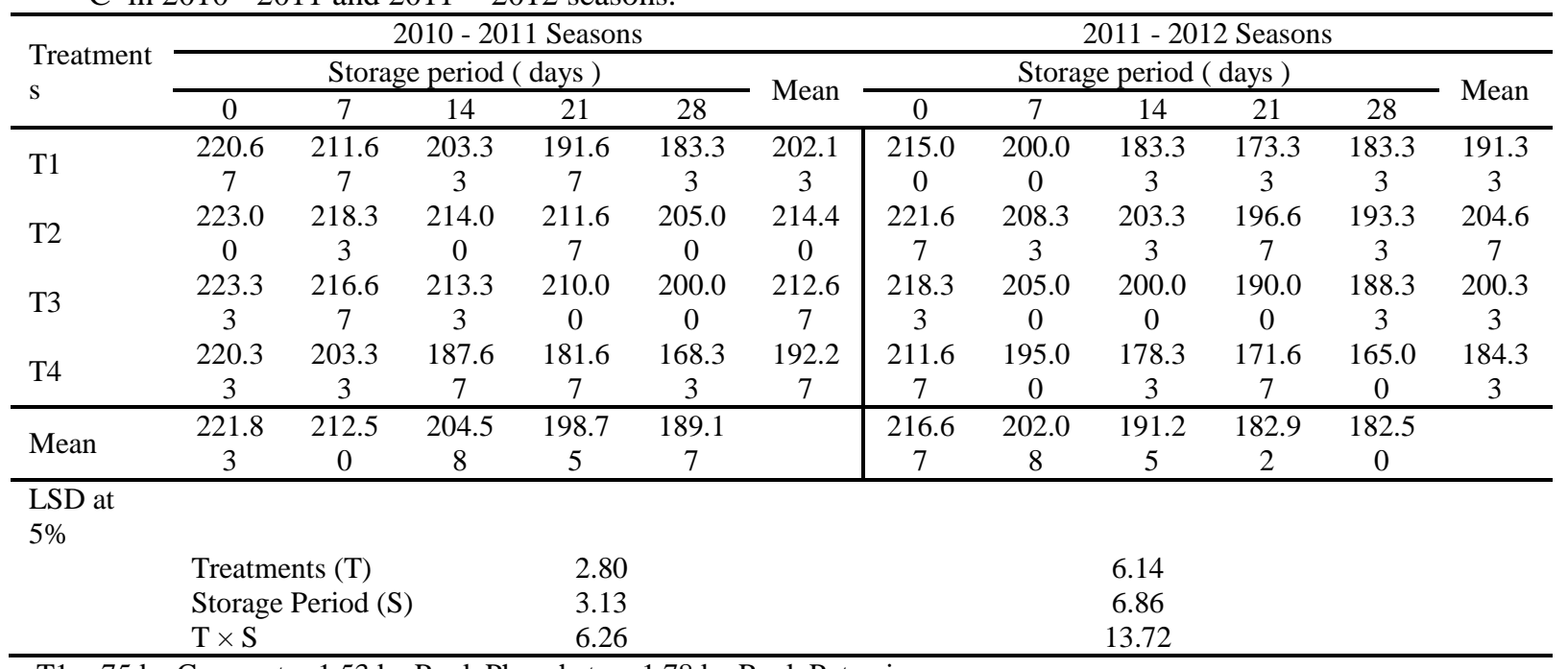

$\mathrm{T} 1=75 \mathrm{~kg}$ Compost $+1.53 \mathrm{~kg}$ Rock Phosphate $+1.78 \mathrm{~kg}$ Rock Potassium.

$\mathrm{T} 2=75 \mathrm{~kg}$ Compost $+1.53 \mathrm{~kg}$ Rock Phosphate $+2.34 \mathrm{~kg}$ Rock Potassium.

$\mathrm{T} 3=75 \mathrm{~kg}$ Compost $+1.53 \mathrm{~kg}$ Rock Phosphate $+3.00 \mathrm{~kg}$ Rock Potassium.

T4 = Mineral fertilization (NPK), Control.

Table 11. Effect of rock potassium fertilization on total soluble solids (\%) of sweet pepper fruit during storage at $10^{\circ} \mathrm{C}$ in $2010-2011$ and $2011-2012$ seasons.

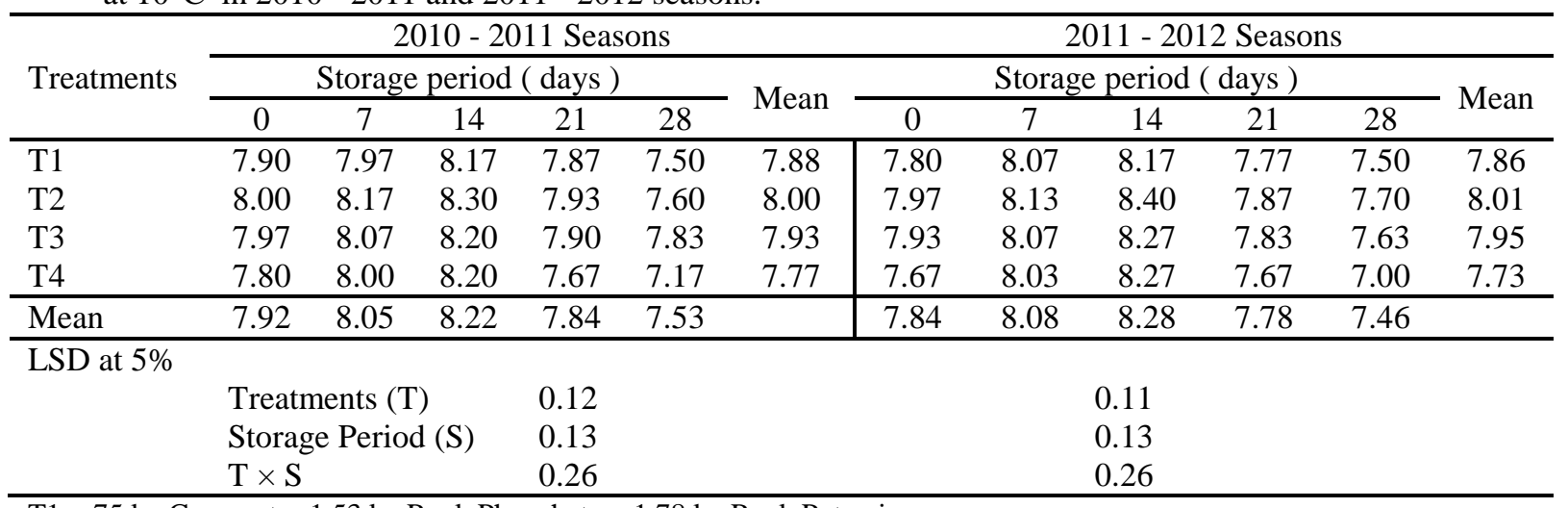

T1 $=75$ kg Compost +1.53 kg Rock Phosphate +1.78 kg Rock Potassium.

$\mathrm{T} 2=75 \mathrm{~kg}$ Compost $+1.53 \mathrm{~kg}$ Rock Phosphate $+2.34 \mathrm{~kg}$ Rock Potassium.

$\mathrm{T} 3=75 \mathrm{~kg}$ Compost $+1.53 \mathrm{~kg}$ Rock Phosphate $+3.00 \mathrm{~kg}$ Rock Potassium.

T4 = Mineral fertilization (NPK), Control.

Table 12. Effect of rock potassium fertilization on ascorbic acid (mg/100g fresh weight) of sweet pepper fruit during storage at $10^{\circ} \mathrm{C}$ in $2010-2011$ and $2011-2012$ seasons.

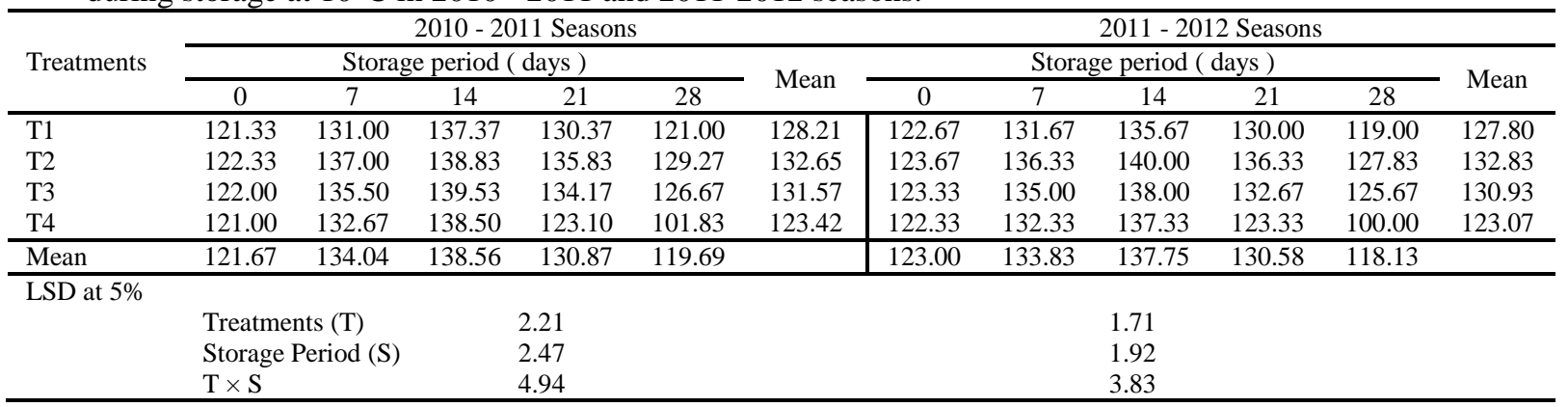

T1 $=75$ kg Compost +1.53 kg Rock Phosphate +1.78 kg Rock Potassium.

$\mathrm{T} 2=75 \mathrm{~kg}$ Compost $+1.53 \mathrm{~kg}$ Rock Phosphate $+2.34 \mathrm{~kg}$ Rock Potassium.

$\mathrm{T} 3=75 \mathrm{~kg}$ Compost $+1.53 \mathrm{~kg}$ Rock Phosphate $+3.00 \mathrm{~kg}$ Rock Potassium.

$\mathrm{T} 4=$ Mineral fertilization (NPK), Control. 
Table 13. Effect of rock potassium fertilization on carotenoids ( $\mathrm{mg} / 100 \mathrm{~g}$ fresh weight) of sweet pepper fruit during storage at $10^{\circ} \mathrm{C}$ in $2010-2011$ and $2011-2012$ seasons.

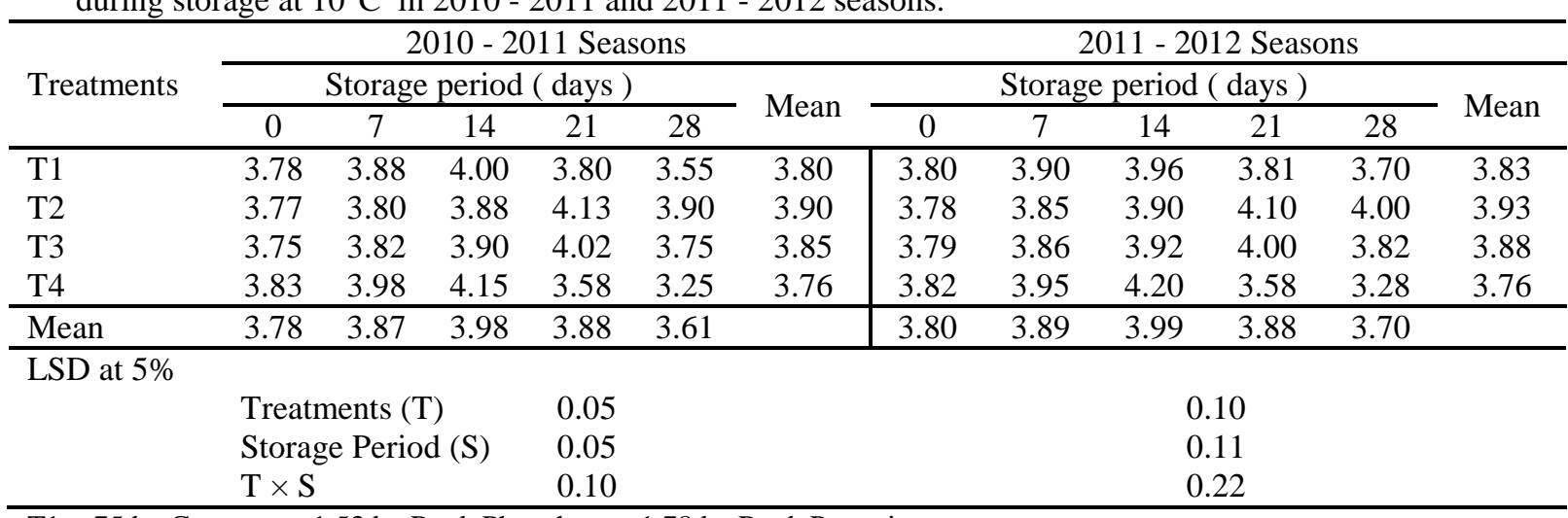

T1 $=75 \mathrm{~kg}$ Compost $+1.53 \mathrm{~kg}$ Rock Phosphate $+1.78 \mathrm{~kg}$ Rock Potassium.

$\mathrm{T} 2=75 \mathrm{~kg}$ Compost $+1.53 \mathrm{~kg}$ Rock Phosphate $+2.34 \mathrm{~kg}$ Rock Potassium.

$\mathrm{T} 3=75 \mathrm{~kg}$ Compost $+1.53 \mathrm{~kg}$ Rock Phosphate $+3.00 \mathrm{~kg}$ Rock Potassium.

T4 = Mineral fertilization (NPK), Control.

\section{Discussion}

Several sweet pepper fertilizer treatments that increase yield have been investigated, but a few works that studied the effect of fertilization on fruit quality have been studied. Organic fertilizer could be an alternative to mineral fertilizers. This study was done to compare between mineral and organic fertilizers on vegetative growth, yield, chemical composition and storage ability of sweet pepper. All vegetative growth parameters, yield and physical fruit parameters were significantly increased when rock potassium was applied at the highest rates (T2 and T3). This may be because mineralization of compost was enhanced by higher temperature under greenhouse conditions and release of $\mathrm{P}$ and $\mathrm{K}$ from rock phosphate and rock potassium, respectively. The best performance of rock potassium plus compost could be attributed to better maintenance of soil nutrients status in the root zone, which in turn helped the plants to utilize nutrients more efficiently, rather of potassium rock place frequently, which favorably affects growth of the crop (Hellal et al., 2009).

The two highest levels of rock potassium had the highest yields (early and total yield). This may be due to the higher rates of potassium release from these treatments. the relatively low vegetative growth, yield and physical fruit parameters of the lowest level of rock potassium, when compared to the two highest level of rock potassium or control, was probably the result of small potassium amount that release from this treatment. The control treatment had almost the same vegetative growth, yield and physical fruit parameters when compared to the highest two levels of rock potassium. The use of potassium feldspars increases the yield response and not greater than yield from conventional fertilizers (Manning, 2010).

These results are in agreement with those obtained by Picha and Hall (1982), Gupta and Sengar
(2000), who stated that these results may be due to major role of potassium element in many physiological and biochemical processes such as cell division, metabolism of carbohydrates and increased photosynthesis. The results are in harmony with the results of Padem and Ocal (1999), who demonstrated that increasing potassium levels led to a significant increase in fruit weight. Potash has major role in translocation of photosynthates and develops healthy fruits with improved weight.

Weight loss was decreased while, TSS, ascorbic acids and carotenoids were increased with the increasing of potassium levels (Table 5). The results are in agreement with Tisdale et al. (1985) who reported that with proper potassium nutrition fruit is generally higher in total soluble solids, carotenoids, sugars and acids and has a longer shelf life. These results could be due to the role of potassium in the biochemical processes. It is required for various metabolic activities and physiological functions (Marschner, 1995).

\section{References}

A.O.A.C., 1980. Quality of Official Analytical Chemists, Washington DC. USA.

Badr, M.A. 2006. Efficiency of K-feldspar combined with organic materials and silicate dissolving bacteria on tomato yield. J. Appl. Sci. Res., 2(12):1191-1198.

El-bassiony, A.M., Fawzy, Z.F., Abd El-samad, E.H and Riad, G.S. 2010. Growth, Yield and fruit quality of sweet pepper plants (Capsicum annuum L.) as affected by potassium fertilization. Journal of American Science. 6 (12):722-729.

El-Masry, T.A. 2000. Growth, yield and fruit quality response in sweet pepper to varying rates of potassium fertilization and different concentrations of paclobutrazol foliar application. Annals Agric. Sci. Moshtohor. 38(2): 1147-1157. 
El-Naggar, A. M. A. 2004. Effect of organic farming on drip irrigation grapevine and soil chemical properties. Proceeding of the 2 nd and International Conference of Agriculture, Cairo, Egypt, pp117-128.

Fawzy, Z.F., Behairy, A.G. and Shehata, S.A. 2005. Effect of potassium fertilizer on growth and yield of sweet pepper plants (Capsicum annuum, L.). Egypt. J. Agric. Res., 2(2): 599-610.

Gupta, C.R. and Sengar, S.S. 2000. Response of tomato (Lycopersicon esculentum Mill.) to nitrogen and potassium fertilization in acidic soil of Bastar. Veg. Sci. 27(1): 94-95.

Hellal, F.A., Abdel-Hady, M. and Ragab, A. A.M. 2009. Influence of organic amendments on nutrients availability and up take by Faba bean plants fertilized by rock phosphate and feldspar. American-Eurasian J. Agric. And Environ. Sci., 6(3): 271-279.

Lester, G. E., Jifon, J. L. and Makus, D.J. 2006. Supplemental foliar potassium applications with or without a surfactant can enhance netted muskmelon quality. Hort. Sci. 41(3): 741-744.

Manning, D.A.C .2010. Mineral sources of potassium for plant nutrition. A Review Agron. Sustain, Dev. pp: 281-294.
Marschner, H. 1995. Mineral nutrition of higher plants. $2^{\text {nd }}$ ed. Academic Press. London. New York.

Nassar, H.H.; Barakat, M.A., El-Masry, T.A. and Osman, A.S. 2001. Effect of potassium fertilization and paclobutrazol foliar application on vegetative growth and chemical composition of sweet pepper. Egypt. J. Hort., 28(1): 113-129.

Padem, H. and Ocal, A. 1999. Effects of humic acid applications on yield and some characteristics of processing tomato. Acta Hort. 487: 159-164.

Picha, D.H. and Hall, C.B. 1982. Influence of K, cultivar and season on tomato gray wall and blotchy ripening. J. Amer. Soc. Hort. Sci. 106:704-708.

Snedecor, G.W. and Cochran,W.G.1980. Statistical Methods. 8th Ed. Iowa State Univ. Press, Ames, Iowa, USA.

Tisdale, S.L., Nelson, W.L. and Beaton, J.D. 1985. Soil and fertilizer potassium. In: Soil Fertility and Fertilizers. 4th ed., S.L. Tisdale, W.L. Nelson and J.D. Beaton (eds.), 249-291, MacMillan Publ. Co., New York.

Usherwood N.R. 1985. The role of potassium in crop quality. In: Munson RS (ed) Potassium in Agriculture ASACSSA-SSSA. Madison, WI, pp 489-513.

\section{تأثير التسميد العضوي والغير العضوي على الإنتاجية والقدرة التخزينية لمحصول الفلقل}

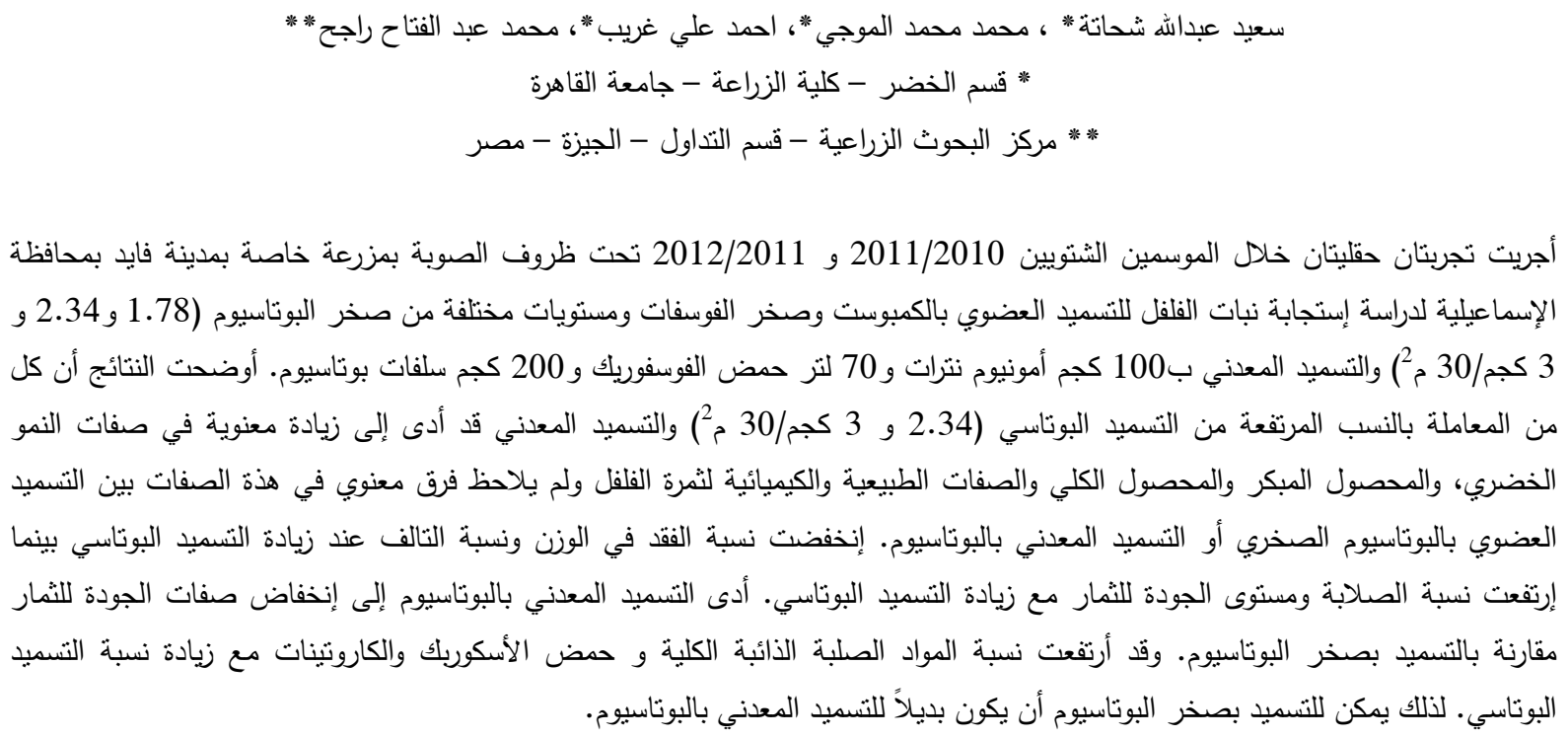

